\title{
An emendation of the genus Hyaloscypha to include Fuscoscypha (Hyaloscyphaceae, Helotiales, Ascomycotina)
}

\author{
HANS-OTTO BARAL, JACQUES R. DE SLOOVER, SEPPO HUHTINEN, TOMI LAUKKA \\ and SOILI STENROOS
}

BARAL, H.-O., DE SLOOVER, J. R., HUHTINEN, S., LAUKKA, T. \& STENROOS, S. 2009: An emendation of the genus Hyaloscypha to include Fuscoscypha (Hyaloscyphaceae, Helotiales, Ascomycotina). - Karstenia 49: 1-17. Helsinki. ISSN 0453-3402.

The monotypic genus Fuscoscypha possesses hairs similar as in the genus Hyaloscypha but differs by grey-olivaceous-brown apothecia with short dark stipes. Molecular data proves that the pigmentation does not permit delimitation of a separate genus, as white and brown taxa do not form separate clades. Followingly, Fuscoscypha is here considered to be a synonym of Hyaloscypha. Three of the here treated four species have an olivaceous-brown excipulum. Two are saprophytes on decaying leaves and fruits of angiosperms: F. acicularum, the type species of Fuscoscypha, and Hyaloscypha fuscostipitata comb. nov. (formerly placed in Betulina). Two are biotrophic parasites on Bryophyta: Hyaloscypha hepaticola comb. nov. (formerly placed in Trichopeziza) and the hyaline-excipled Hyaloscypha albocarpa spec. nov. which is otherwise very similar to $H$. hepaticola. The type species of the genus Betulina, B. hirta, is found to be an earlier synonym of Urceolella salicicola $(=U$. graddonii). The new combination Urceolella hirta is therefore proposed, hence Betulina is considered a synonym of Urceolella.

Key words: Hyaloscyphaceae, Hyaloscypha, Fuscoscypha, Betulina, Urceolella, bryophilous ascomycetes

Hans-Otto Baral, Blaihofstrasse 42,D-72074Tübingen; e-mail: zotto@arcor.de

Jacques R. De Sloover, Research Centre on Biodiversity, Université Catholique de Louvain, 1348 Louvain-la-Neuve, Belgium; e-mail: deslooverj@scarlet.be

Seppo Huhtinen, Herbarium, University of Turku, FI-20014 Turku, Finland; e-mail: seppo.huhtinen@utu.fi

Tomi Laukka, University of Turku,FI-20014Turku, Finland;. e-mail: tomi.laukka@utu.fi

Soili Stenroos, Finnish Museum of Natural History, P.O. Box 7, FI-00014 Helsinki University, Finland, e-mail: soili.stenroos@helsinki.fi

\section{Introduction}

The genus Betulina was created by Velenovský (1947: 138) for a single taxon, B. hirta Velen., having rather large $(1-1.5 \mathrm{~mm})$, pure white, long-haired apothecia thriving on wet decaying birch leaves in Bohemia. Velenovský compared it with the genus Hyaloscypha Boud., from which he separated it by stipitate apothecia and extraordinarily long $(1 \mathrm{~mm})$ and narrow (hardly
$2 \mu \mathrm{m})$, cylindrical, flexuous hairs without lumen. Graddon (1974: 477) linked with Velenovský's genus Betulina a species he discovered in Britain, likewise on birch leaves, B. fuscostipitata Graddon. The assignment of this species to Betulina sounds rather inappropriate, considering the quite differently shaped hairs being short, 
straight, gradually narrowed towards apex, thinwalled, and bearing lumps of resinous exudate. The hairs of B. fuscostipitata closely resemble those of Hyaloscypha in the modern circumscription (Velenovský 1934 included also species with cylindrical hairs in Hyaloscypha). Graddon refrained from placing his species in Hyaloscypha because of the stipitate apothecia, the stipe being distinctly higher than wide.

In his monograph of Hyaloscypha and allied genera, Huhtinen (1990) reported that no type material of Betulina hirta exists. From the protologue he suggested a possible identity with Hyalopeziza ciliata although the solid hairs were described much longer and narrower than known for $H$. ciliata. Furthermore, Huhtinen explicitly suggested that Graddon's B. fuscostipitata and a similar unnamed Japanese collection might deserve a new genus, which he saw to be morphologically related to both Hyaloscypha and Dematioscypha Svrček. The latter genus resembles B. fuscostipitata in its dark brown color of the excipular cells, but the cells are shorter and wider (brick-shaped to almost globose from base to margin), a distinct stipe is lacking, the asci are IKI-, and a conspicuous mononematous anamorph (Haplographium) with long black-brown setae is regularly associated. Similarly, the genus Phaeoscypha Spooner (in Kirk \& Spooner 1984: 574) resembles B. fuscostipitata in the brown excipulum and even hair shape, but differs by short-celled excipular cells, a very short stipe, rather large asci and spores, and a conspicuous mononematous anamorph (Chalara). So Huhtinen's conclusion was to wait new material before establishing a new genus for Graddon's taxon.

In spring 1999, a tiny stipitate dark brown Hyaloscyphaceae was found by one of us (JDS) in the High Ardennes (Belgium) in an open Vaccinium bog: it was thriving as a biotrophic parasite on a leafy liverwort (Cephaloziella divaricata), a genus belonging to the smallest liverworts known in Central Europe. Later three further collection sites in western Germany came to our notice: the bryologist and ecologist Peter Wolff had noted the very same species since 1988 , exclusively on Cephaloziella rubella. As he kindly sent us fresh collections, we (HOB \& JDS) could verify full agreement with the find from Belgium. Based on our illustrations, the expert for bryophilous ascomycetes Dr. Peter Döbbeler identified the species as Trichopeziza hepaticola Grelet \& Croz. which he knew only from the literature. Although the type material was not reexamined by us, the protologue and the identical host genus leaves little doubt about the identity of our specimens.

For most of its characters, this discomycete appears closely related to Graddon's Betulina fuscostipitata. So we decided to reconsider the genus Betulina by studying the type species, $B$. hirta. In the meantime the holotype was located at PRM (Praha) and on request sent to one of us (JDS), intending to redefine a genus that apparently could now encompass three species. It appeared at once, however, that neither Graddon's species nor our own taxon had anything to do with Betulina hirta: this one looked as a tiny short-stipitate pure white Hyaloscyphaceae, the excipulum of which was clothed with very long, flexuous, glassy hairs with a narrow lumen to the apex. From the type convolute it was evident that as early as in 1980 Svrček had revised the holotype and with good reason transferred $B$. hirta to Urceolella Boud. as U. hirta (Velen.) Svrček ined. Furthermore, he had established that $U$. salicicola Raschle is a synonym (in the "revidit" label). Though not often reported, this foliicolous species seems to be widely distributed and to grow on a range of hosts, viz. Betula, Populus, Quercus and Salix (Baral \& Krieglsteiner, 1985; Raitviir \& Galán, 1993, as Urceolella graddonii nom. nov.). The following new combination is therefore proposed:

Urceolella hirta (Velen.) Svrček, De Sloover \& Baral comb. nov.

Basionym: Betulina hirta Velen., Opera Bot. Cechica 4: 138 (1947).

EUrceolella salicicola Raschle, Sydowia 39: 215 (1977, 1976-1977) E Hyalotricha salicicola Graddon, Trans. Br. mycol. Soc. 69: 262 (Oct. 1977) 三 Urceolella graddonii Raitv. \& R. Galán nom. nov., Sydowia 45: 49 (1993).

MycoBank no.: MB513058

Among the known genera of Hyaloscyphaceae, the morphology of Betulina fuscostipitata seems to resemble most closely the description of the monotypic genus Fuscoscypha Svrček (1987). This genus was established for Lachnum acicularum Velen. (on leaves of Pinus), which is so far known with certainty only from the sparse type collection. Though having hyaline, gradually tapered hairs much resembling those of 
Hyaloscypha, Svrček separated Fuscoscypha at the generic level because of an ectal excipulum of a grey-brown textura oblita, while species of Hyaloscypha have completely hyaline apothecia and a non-gelatinized t. prismatica-angularis. $F$. acicularum and B. fuscostipitata are also similar in their ecology (saprobes on leaves of coniferous vs. broad-leaved trees). The main difference seems to lie in the ectal excipulum, being t. oblita in $H$. acicularum but a rather thin-walled $t$. prismatica-angularis in B. fuscostipitata. Trichopeziza hepaticola differs from these two species in larger asci and spores, simple-septate ascogenous hyphae, and in being parasitic on liverworts, while the excipulum concurs quite well with that of $B$. fuscostipitata. Moreover, resinous exudates have never been observed in T. hepaticola while present in the two saprophytic species.

Despite such divergences it seems reasonable, in our opinion, to consider the three taxa congeneric. Re-examination of the holotype of Lachnum acicularum by one of us (HB) revealed so little differences to Betulina fuscostipitata, examined from two personal collections, that even the species limits become questionable. The ectal excipulum of the former was found to be of a t. prismatica with thick brown walls, the thin septa of the comparatively short cells being only visible in CR (possibly Svrček overlooked some of the septa), and the wall thickness appears to represent only a gradual difference to the much more thin-walled excipulum of B. fuscostipitata. Contrary to Svrček's report of inamyloid asci, Fuscoscypha acicularum possesses a minute hemiamyloid ring that becomes evident only when $\mathrm{KOH}$-pretreated, while the ring in B. fuscostipitata reacts blue in IKI without such a treatment (euamyloid). When Huhtinen (1990: 53) reexamined the holotype of $L$. acicularum he did not mention any similarities with $B$. fuscostipitata but instead compared it with Hamatocanthoscypha Svrček, in which genus brown species were already placed. The observed differences between Fuscoscypha (ectal excipulum of t. oblita and narrowly conical, non-uncinate hairs) and Hamatocanthoscypha convinced Huhtinen to accept Fuscoscypha as a separate genus.

Hairs of the Hyaloscypha-type are also known in a number of species which Baral (1989) included in the genus Calycellina Höhn. whilst Huhtinen (1990) separated them in Phialina Höhn. by restricting Calycellina to taxa with cy- lindrical hairs. Calycellina s.l. is characterized by refractive vacuoles in the living paraphyses and hair bases and herein sharply differs from both Betulina fuscostipitata and Trichopeziza hepaticola which are devoid of such vacuoles (future fresh finds of $H$. acicularum should be tested for this vital character). Svrček stressed the basal dark brown ring of the apothecia as characteristic of Fuscoscypha, a feature also very typical of Calycellina. While the main characteristics of the genus Fuscoscypha appear to be the dark brown pigment and a distinct stipe, three deviating collections of a bryophilous fungus came to our notice having completely white, usually sessile apothecia. The hosts were Calypogeia, Cephalozia and Tetraphis growing over tree bases in acidic coniferous forests. Considering the almost identical morphology of the hymenial elements and hairs, this colourless taxon is undoubtedly congeneric with $T$. hepaticola, hence the taxonomic value of both the brown pigment and stipe in Fuscoscypha and the limits against Hyaloscypha become questionable. Because of the deviating hosts and a few differing microscopic characteristics of more or less ambiguous taxonomic value, we here tentatively describe the white taxon as a new species. The present molecular results on $T$. hepaticola confirm that the brown pigment has little taxonomical value, at least at the generic level. Hence, we here consider all four investigated species as members of Hyaloscypha.

\section{Materials and methods}

\section{Morphological study}

The material was studied with an Olympus BX40 research microscope and a Zeiss Standard 20 using bright field optics. Media and staining procedures used were those given in Baral (1992) and Huhtinen (1990), and their abbreviations are: MLZ (Melzer's reagent), IKI (1\% Lugol's solution), $\mathrm{CB}=$ Cotton blue in lactophenol, $\mathrm{CR}$ (ammoniacal Congo red), $\mathrm{CRB}=$ Cresyl blue (aqueous), $\mathrm{KOH}(5 \%$ aqueous solution). $\uparrow$ sign refers to observations from dead cells, * sign to observations from living cells. Categories of relative lipid (oil) content: $0=$ no oil content, $5=$ maximum oil content. The number of collections (= populations) from which the data derive are given in \{\} . H.B. = herbarium H.-O. Baral. Colour coding follows Cailleux (1981). 


\section{Molecular study}

Taxon sampling: To test the placement of Hyaloscypha hepaticola, representatives of Hyaloscypha and two other genera (Lachnum and Arachnopeziza) from the traditional family Hyaloscyphaceae (including Lachnaceae) were included as ingroup taxa. Hymenoscyphus fructigenus and Cyathicula microspora (traditional family Helotiaceae) were selected as outgroup taxa. 15 specimens of 11 species were used in this study (Table 1). All herbarium specimens used in DNA extraction are deposited in TUR.

Table 1. Taxa used in this study.

\begin{tabular}{|c|c|c|c|c|c|c|c|}
\hline \multirow[b]{2}{*}{ Taxon } & \multirow[b]{2}{*}{ ID } & \multirow[b]{2}{*}{ Origin \& collector } & \multicolumn{5}{|c|}{ GenBank accession number } \\
\hline & & & LSU & betatubulin & RPB2 & ITS & mtSSU \\
\hline $\begin{array}{l}\text { Arachnopeziza variepilosa } \\
\text { (R. Galán \& Raitv.) Huhtinen }\end{array}$ & M337 & $\begin{array}{l}\text { Canada, Yukon, Huhtinen } \\
87 / 131\end{array}$ & EU940086 & FJ477045 & - & EU940163 & - \\
\hline Cyathicula microspora Velen. & M267 & Sweden, Frøslev 2006-B1 & EU940088 & FJ477046 & EU940304 & EU940165 & EU940240 \\
\hline Hyaloscypha hepaticola & M171 & Finland, Nieminen 10 & EU940118 & FJ477047 & EU940330 & EU940194 & EU940266 \\
\hline Hyaloscypha hepaticola & M339 & Finland, Kukkonen 37 & EU940150 & FJ477048 & EU940359 & EU940226 & EU940290 \\
\hline $\begin{array}{l}\text { Hyaloscypha albohyalina var. } \\
\text { spiralis (Velen.) Huhtinen }\end{array}$ & M259 & Finland, Nieminen 28 & EU940151 & FJ477049 & EU940360 & EU940227 & EU940291 \\
\hline $\begin{array}{l}\text { Hyaloscypha aureliella (Nyl.) } \\
\text { Huhtinen }\end{array}$ & M234 & UK, Scotland, Huhtinen 05/56 & EU940152 & FJ477050 & EU940361 & EU940228 & EU940292 \\
\hline Hyaloscypha aureliella & M235 & $\begin{array}{l}\text { Finland, Söderholm, } 6 \text { Sept. } \\
2005\end{array}$ & EU940153 & FJ477051 & EU940362 & EU940229 & EU940293 \\
\hline $\begin{array}{l}\text { Hyaloscypha daedaleae } \\
\text { Velen. }\end{array}$ & & GenBank & AY789415 & - & - & AY789416 & - \\
\hline Hyaloscypha fuckelii Nannf. & M233 & $\begin{array}{l}\text { UK, Scotland, Leonard, } 25 \\
\text { Aug. } 2005\end{array}$ & EU940154 & FJ477052 & EU940363 & EU940230 & EU940294 \\
\hline $\begin{array}{l}\text { Hyaloscypha vitreola } \\
\text { (P. Karst.) Boud. }\end{array}$ & M39 & Finland, Söderholm 3400 & EU940155 & FJ477053 & EU940364 & EU940231 & EU940295 \\
\hline Hyaloscypha vitreola & $\mathrm{M} 220^{\mathrm{a}}$ & Finland, Huhtinen 05/71 & FJ477058 & FJ477054 & FJ477057 & FJ477059 & - \\
\hline Hyaloscypha vitreola & M236 & Finland, Laukka 229 & EU940156 & FJ477055 & - & EU940232 & EU940296 \\
\hline $\begin{array}{l}\text { Hymenoscyphus fructigenus } \\
\text { (Bull.) Fr. }\end{array}$ & M159a & $\begin{array}{l}\text { Finland, Heinonen \& } \\
\text { Heinonen } 708\end{array}$ & EU940157 & FJ477056 & EU940365 & EU940233 & EU940297 \\
\hline $\begin{array}{l}\text { Lachnum cf. bicolor } \\
\text { (Bull.) P. Karst. }\end{array}$ & & GenBank & AY544674 & - & - & AJ430394 & AY544744 \\
\hline $\begin{array}{l}\text { Lachnum virgineum (Batsch) } \\
\text { P. Karst. }\end{array}$ & & GenBank & AY544646 & - & DQ470877 & DQ491485 & AY544745 \\
\hline
\end{tabular}

a DNA extracted from apothecia; all others were extracted from cultures

Fungal cultures and DNA extraction: Ascospores or apothecia (M39) were cultured on $2 \%$ malt extract agar (MEA) containing chloramphenicol. Mycelia were allowed to grow for approximately two months in room temperature. For observations on cultural morphology the strains were grown at $+15^{\circ} \mathrm{C}$ with a combination of $12 / 12$ $\mathrm{h}$ of light and darkness. The diameter was measured at two week intervals. DNA was extracted from cultures or directly from ascomata, the number of apothecia picked depending on their size. Extractions were performed with QIAamp ${ }^{\circledR}$ DNA Mini Kit (Qiagen) according to the manufacturer's protocol.

Amplification and purification: Five different gene loci were amplified: partial rDNA LSU (ca. $1300 \mathrm{bp}$ ), partial betatubulin (ca. 700 bp), partial RPB2 (ca. 900 bp), par- tial mitochondrial rDNA SSU (ca. $1100 \mathrm{bp}$ ) and rDNA ITS (including ITS1, 5.8S and ITS2; ca. $500 \mathrm{bp}$; for primers, see Table 2). illustra ${ }^{\mathrm{TM}}$ puReTaq Ready-To-Go PCR Beads (GE Healthcare) were used in the amplification and the reactions were performed with GeneAmp ${ }^{\circledR}$ PCR System 9700 (PE Applied Biosystems).

The PCR profile was $60 \mathrm{~s}$ at $95^{\circ} \mathrm{C}$ (denaturation), 60 $\mathrm{s}$ at $52^{\circ} \mathrm{C}$ (LSU), $56{ }^{\circ} \mathrm{C}$ (betatubulin), $55^{\circ} \mathrm{C}$ (RPB2) or $60^{\circ} \mathrm{C}$ (ITS; annealing), and $60 \mathrm{~s}$ at $72^{\circ} \mathrm{C}$ (extension). 30 cycles were used, preceded by $5 \mathrm{~min}$ at $95^{\circ} \mathrm{C}$ (initial denaturation) and followed by $7 \mathrm{~min}$ at $72^{\circ} \mathrm{C}$ (final extension). For mtSSU rDNA, 35 cycles were used. Denaturation and annealing times were $30 \mathrm{~s}$, and annealing temperatures were $52^{\circ} \mathrm{C}$ for cycles $1-5$ and $50^{\circ} \mathrm{C}$ for cycles 6-35. Two different primer sets were used to amplify and sequence ITS. At first, ITS1-F and ITS4 were used as PCR primers and ITS5 and ITS2-KL as sequencing primers. However, PCR with ITS1-F and ITS4 occasionally 
yielded double bands on gel, as an intron position at the end of SSU is located in the amplified area. To dispose of this problem ITS1-LM and ITS2-KL were used as both PCR and sequencing primers. The obtained PCR products were purified with illustra ${ }^{\mathrm{TM}}$ GFX PCR DNA and Gel Band Purification Kit (GE Healthcare) according to the manufacturer's protocol.

Sequencing: BigDye Terminator Cycle Sequencing Ready Reaction Kit version 1.1 (Applied Biosystems) was used for the sequencing reactions. Sequencing reactions were run using the same equipment as for the PCR. A 25-cycle sequencing schedule with a denaturation temperature of $96^{\circ} \mathrm{C}$ for $30 \mathrm{~s}$, an annealing temperature of $50^{\circ} \mathrm{C}$ for $15 \mathrm{~s}$, and an extension temperature of $60^{\circ} \mathrm{C}$ for $4 \mathrm{~m}$ was performed. The post-reaction purification of the samples was done using Montage SEQ96 Sequencing Reaction Cleanup Kit (Millipore) according to manufacturer's protocol. Sequencing was carried out with MegaBACE 1000 DNA Analysis System (GE Healthcare). Part of the sequence data was acquired as outsourcing service from Macrogen Inc. in Seoul, South Korea. According to their web page, sequencing is conducted under BigDye Terminator cycling conditions. Products are purified using ethanol precipitation and sequenced with 3730xl DNA Analyzer (Applied Biosystems). Primers used in sequencing are listed in Table 2.

Table 2. Primers used in PCR and sequencing.

\begin{tabular}{|c|c|c|c|}
\hline Primer & Sequence & Type & Reference \\
\hline LROR & ACCCGCTGAACTTAAGC & PCR, sequencing & Cubeta et al. (1991) \\
\hline LR7 & TACTACCACCAAGATCT & PCR, sequencing & Vilgalys \& Hester (1990) \\
\hline LR3R & GTCTTGAAACACGGACC & sequencing & Rehner \& Samuels (1995) \\
\hline LR5 & TCCTGAGGGAAACTTCG & sequencing $^{\mathrm{a}}$ & Rehner \& Samuels (1995) \\
\hline LR3 & CCGTGTTTCAAGACGGG & sequencing ${ }^{\mathrm{a}}$ & Rehner \& Samuels (1995) \\
\hline BT3-LM & GAACGTCTACTTCAACGAG & PCR, sequencing & Myllys et al. (2001) \\
\hline BT10-LM & TCGGAAGCAGCCATCATGTTCTT & PCR, sequencing & Myllys et al. (2001) \\
\hline fRPB2-7cF & ATGGGYAARCAAGCYATGGG & PCR & Liu et al. (1999) \\
\hline fRPB2-11aR & GCRTGGATCTTRTCRTCSACC & PCR & Liu et al. (1999) \\
\hline RPB2-7F & ATGGGKAAGCARGCWATGGG & sequencing & Liu et al. (1999) \\
\hline RPB2-3053R & TGRATYTTRTCRTCSACCATRTG & sequencing & Reeb et al. (2004) \\
\hline ITS1-LM & GAACCTGCGGAAGGATCATT & PCR, sequencing & Myllys et al. (1999) \\
\hline ITS2-KL & ATGCTTAAGTTCAGCGGGTA & PCR, sequencing & Lohtander et al. (1998) \\
\hline ITS1-F & CTTGGTCATTTAGAGGAAGTAA & PCR & Gardes \& Bruns (1993) \\
\hline ITS4 & TCCTCCGCTTATTGATATGC & PCR & White et al. (1990) \\
\hline ITS5 & GGAAGTAAAAGTCGTAACAAGG & sequencing & White et al. (1990) \\
\hline mtSSU1-KL & AGTGGTGTACAGGTGAGTA & PCR, sequencing & Lohtander et al. (2002) \\
\hline mtSSU2-KL & ATGTGGCACGTCTATAGCCCA & PCR, sequencing & Lohtander et al. (2002) \\
\hline
\end{tabular}

${ }^{a}$ used as alternative sequencing primers

Parsimony analyses: The sequences were constructed with SeqMan 4.0 (DNASTAR), aligned with ClustalX 1.8 (Thompson et al. 1997) using default parameters and refined manually. Introns were removed. Analysis was carried out with PAUP 4.0 b 10 (Swofford 2002). Combined data matrix consisted of 15 taxa and 4650 char- acters, of which 3556 were constant, 324 variable but parsimony-uninformative and 770 parsimony-informative. Gaps were treated as fifth base. Branch-and-bound search was utilized with default parameters. Branch support was estimated by performing 1000 bootstrap replicates. 


\section{Results and discussion}

\section{Phylogeny}

The cladistic analysis produced three equally parsimonious trees of length 2029 with consistency index (CI) of 0.740 and retention index (RI) of 0.707. A strict consensus tree was calculated (Fig. 1). Genus Hyaloscypha is monophyletic with $89 \%$ bootstrap support, and the dark-excipled $H$. hepaticola is nested inside hyaline species of Hyaloscypha.

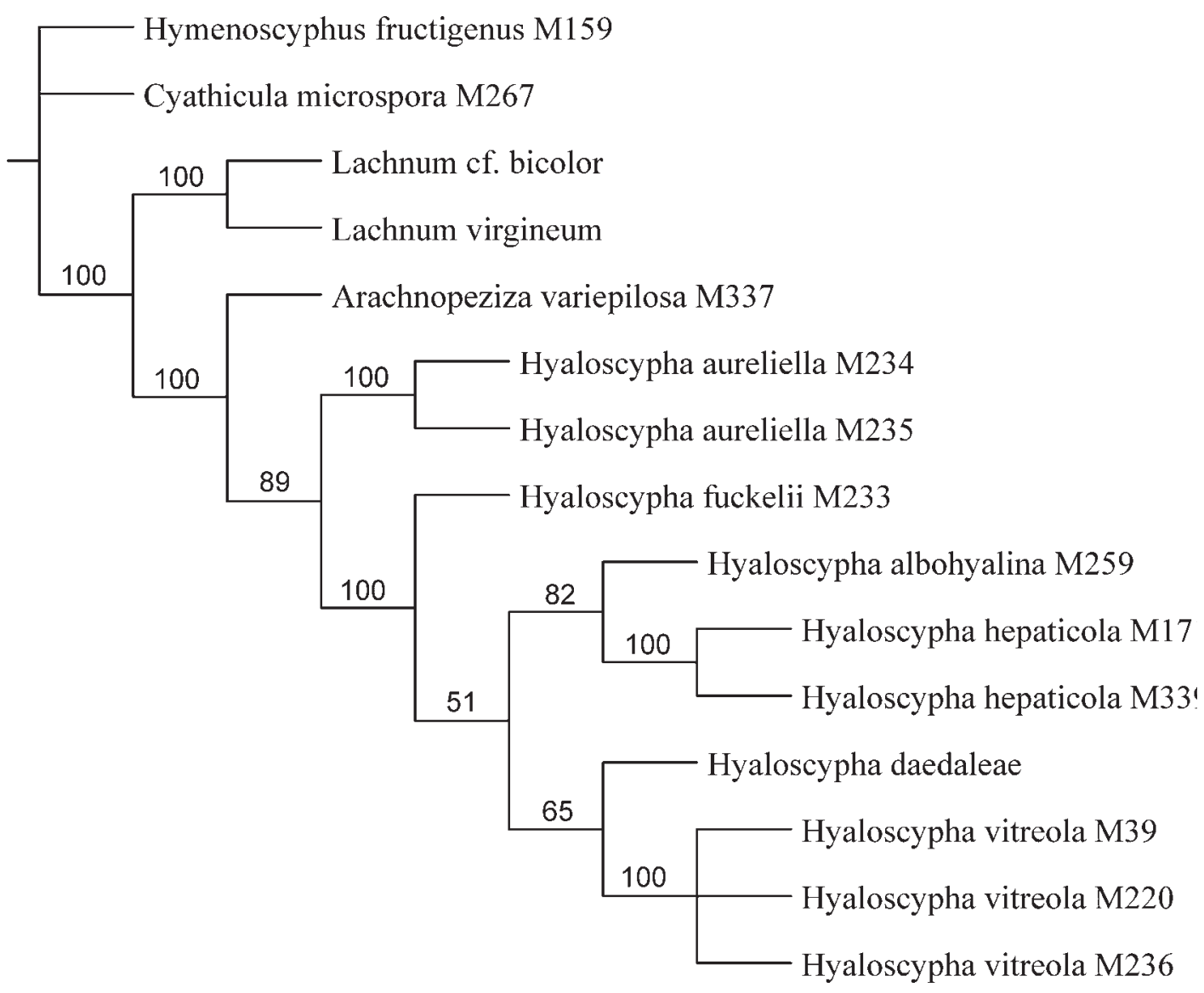

Fig. 1. Strict consensus tree obtained from the branch-and-bound analysis of a combined dataset consisting of LSU, betatubuline, RPB2, ITS and mtSSU. Bootstrap support values are shown at nodes. 


\section{Morphotaxonomic treatment}

\section{Key to the species of Hyaloscypha treated here}

1. Biotrophic parasites on mosses, asci $* 43-108 \times 6.5-11.3 \mu \mathrm{m}(\dagger 47-86 \times 5-8.8 \mu \mathrm{m})$, arising from simple septa, apical dome $\dagger 0.9-2 \mu \mathrm{m}$ thick, ascospores *5.5-12.5 $\times 2.8-4 \mu \mathrm{m}, \quad(\dagger 5.5-9 \times 2.3-3.5$ $\mu \mathrm{m})$ with a low to high oil content, hairs in $\mathrm{H}_{2} \mathrm{O}$ smooth, without exudate, apices $1-1.5(-2.5) \mu \mathrm{m}$ wide, apothecia entirely white, sessile or stipitate, or grey-brown with a dark brown stipe, pigment unchanged in $\mathrm{KOH}$, ectal excipulum on flanks 30-80 $\mu \mathrm{m}$ thick.....

- Saprophytes on decaying leaves and fruits, asci *28-50 × 5.5-6(-7?) $\mu \mathrm{m}(\dagger 28-42.5 \times 5-6.3 \mu \mathrm{m})$, arising from croziers, apical dome $\dagger 0.2-1 \mu \mathrm{m}$ thick, ascospores $* 5-8 \times 1.6-2.3 \mu \mathrm{m}(\dagger 5-9 \times 1.5-1.9$ $\mu \mathrm{m})$, with a very low oil content, hairs fresh in $\mathrm{H}_{2} \mathrm{O}$ smooth or finely rough, partly covered by hyaline to yellowish-brownish MLZ-soluble granules or lumps, apices $0.5-1.2 \mu \mathrm{m}$ wide, apothecia greybrown, with a dark brown stipe, pigment turning olivaceous in $\mathrm{KOH}$, ectal excipulum on flanks 10-12 $\mu \mathrm{m}$ thick

2. Apothecia grey-brown with dark stipe, excipular cells on lower flanks *4-19 $\times 3.5-9 \mu \mathrm{m}$, on Cephaloziella, Lophozia and Ptilidium, asci often with a basal protuberance

H. hepaticola

- Apothecia entirely hyaline, often sessile, excipular cells on lower flanks *7-23 × 6-15 $\mu \mathrm{m}$, on Calypogeia, Cephalozia and Tetraphis, asci never with a basal protuberance

H. albocarpa

3. Ectal excipulum on flanks of t. prismatica with $1-1.5 \mu \mathrm{m}$ thick common walls, ascus apical dome $\dagger 0.2 \mu \mathrm{m}$ thick, on needles of Pinus

H. acicularum

- Ectal excipulum on flanks of t. prismatica-angularis with $0.2-0.3 \mu \mathrm{m}$ thick common walls, ascus apical dome $\dagger 0.4-1 \mu \mathrm{m}$ thick, on leaves and fruits of Carpinus, Castanea, Rubus....H. fuscostipitata

Hyaloscypha hepaticola (Grelet \& Croz.) Baral, Huhtinen \& De Sloover comb. nov. - Figs. 2-4

Basionym: Trichopeziza hepaticola Grelet \& Croz. in Grelet, Bull. trim. Soc. mycol. Fr. 41: 85 (1925).

MycoBank no.: MB513059

Apothecia scattered or gregarious in very small groups, fresh $0.2-0.7(-1) \mathrm{mm}$, dry $0.2-0.4 \mathrm{~mm}$ in diam, with cylindrical, \pm hidden stipe $0.08-0.2$ $\mathrm{mm}$ long, $0.08-0.12 \mathrm{~mm}$ thick, totally $0.3-0.4$ $\mathrm{mm}$ high, receptacle $0.15-0.2 \mathrm{~mm}$ thick, softfleshed, disc slightly concave, finally flat, fresh deep ash-grey, margin finely whitish fimbriate, externally deep greyish-olivaceous to brownishblack, dry apothecia uniformly black, seemingly smooth but densely covered by short, appressed hairs, stipe dark brown to black. Hairs on mid flanks and margin 20-50 × (2-)2.3-3(-4) $\mu \mathrm{m}$, straight to more or less flexuous, somewhat lageniform, with a shorter or longer, narrow-cylindrical apical part 1-1.5(-2) $\mu \mathrm{m}$ wide, apex rounded, pale to light greyish-brown throughout, more or less hyaline at margin, aseptate or sometimes with a septum near base, thin-walled, smooth, without exudate $\left(\mathrm{H}_{2} \mathrm{O}\right)$, MLZ-, protruding near margin for $10-20 \mu \mathrm{m}$, at lower flanks shorter, cylindrical, light brown, appressed to receptacle, somewhat agglutinate, in surface view undulating by forming a regular network. Ectal excipulum pale to bright (ochraceous-)brown (inner parts paler), unchanged in $\mathrm{KOH}$, thin-walled, cortical cells more firm-walled, non-gelatinized, $30-40 \mu \mathrm{m}$ thick on lower flanks, of textura angularis-prismatica oriented at a $45-90^{\circ}$ angle to the surface, cells *4-11(-19) $\times(3.5-) 5-7(-9) \mu \mathrm{m}$ $\{2\}$, on mid flanks of $25 \mu \mathrm{m}$ thick t. prismatica oriented at $10-45^{\circ}$, cells $* 5-15 \times 2.5-6.5 \mu \mathrm{m}$, at margin of hyaline or pale brown t. porrecta oriented at $10-20^{\circ}$. Medullary excipulum hyaline, 

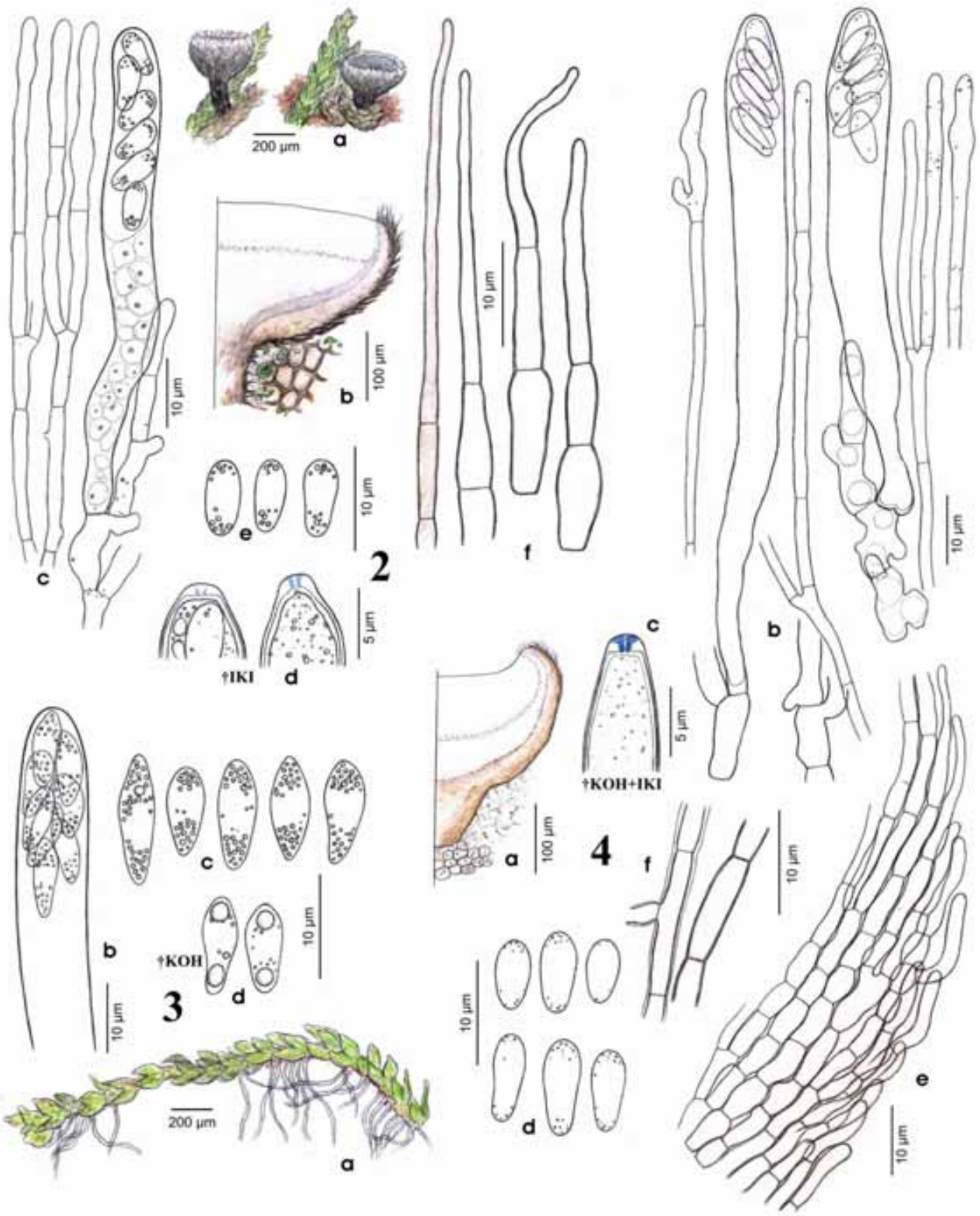

Figs. 2-4. Hyaloscypha hepaticola. Fig. 2. H.B. 6377. Fig. 3. H.B. 7120. Fig. 4. H.B. 7111. - 2a) Fresh apothecia on Cephaloziella divaricata. 2b) Median section of an apothecium. 2c) Ascus with simple-septate base, paraphyses. 2d) Ascus apices. 2e) Ascospores, 2f) Marginal hairs. - 3a) Cephaloziella rubella infected by H. hepaticola. 3b) Ascus top with spores tightly arranged at the apex. 3c-d) Mature ascospores. - 4a) Median section of an apothecium. 4b) Asci with simple-septate bases, paraphyses. 4c) Ascus apex. 4d) Ascospores. 4e) Ectal excipulum and appressed hairs on mid flanks. 4f) Detail of anchoring hyphae. - Del. H.-O. Baral. 

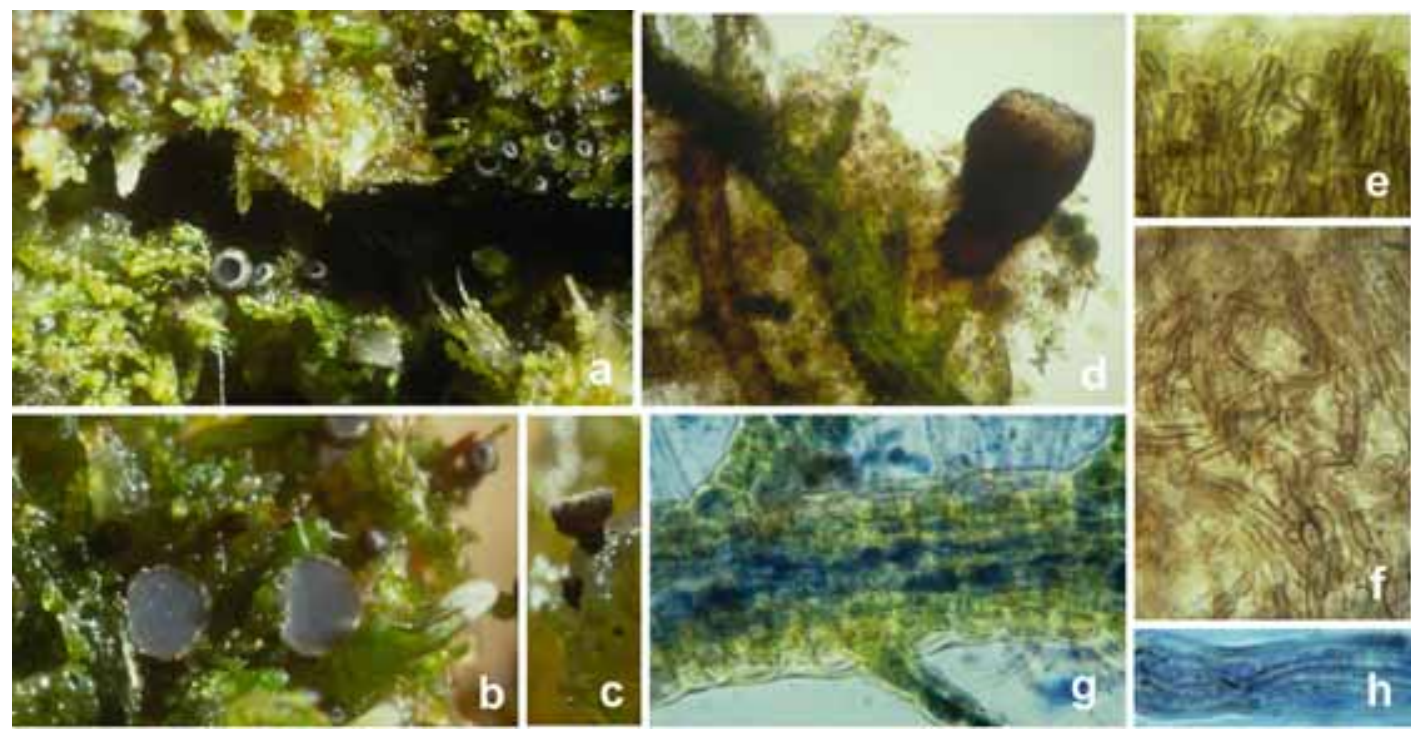

Fig. 5. Hyaloscypha hepaticola. HB 6377. - 5a-d) Fresh apothecia on Cephaloziella divaricata (a, c, d rather young, b mature). 5e-f) External view on apothecium showing hairs on margin (e) and flanks (f). 5g) Caulidia of Cephaloziella with internal hyphae of $H$. hepaticola among the cells of the axis (in CB). 5h) Rhizoid of Cephaloziella with hyphae in their lumen (in CB). - Photo J. De Sloover.

in centre of upwards oriented dense t. intricata, on flanks 10-15 $\mu \mathrm{m}$ thick, of t. porrecta. Anchoring hyphae abundant, forming a very loose t. intricata, hyaline or very pale brownish, very long, *1.8-2.6(-3) $\mu \mathrm{m}$ thick $\{2\}$, covered by a thin or thick hyaline gel sheath staining deep blue-violet in CRB, wall smooth, including gel $0.2-0.6 \mu \mathrm{m}$ thick. Asci cylindric-clavate, *(52-)70-95(-108) $\times(6.7-) 7.5-9.5(-11.3) \mu \mathrm{m}\{2\}, \dagger(47-) 55-78(-$ $86) \times(5.4-) 6-7(-7.8) \mu \mathrm{m}$ in $\mathrm{KOH}\{3\}, \dagger 52-82$ $\times 5.5-7.0(-8.8) \mu \mathrm{m}$ in CR $\{2\}, \overline{\mathrm{x}}=65.6 \times 6.2 \mu \mathrm{m}$ $(\mathrm{n}=16)$, protruding $* 5-10 \mu \mathrm{m}$ beyond paraphyses when mature, 8-spored, pars sporifera *19-30 $\mu \mathrm{m}$ long (biseriate), $\uparrow 26-32 \mu \mathrm{m}$ long (biseriate to subbiseriate), apex medium to strongly conical, apical ring pale to medium strongly blue in IKI (BB), blue in MLZ (euamyloid) $\{8\}$, Calycinatype, arising from simple septa $\{14\}$, typically with a basal aseptate protuberance. Ascospores ellipsoid to ellipsoid-clavate or fusoid to fusoidclavate, aseptate, developing one septum with old age, *(6-)7-11(-12.5) × (2.8-)3-3.8(-4) $\mu \mathrm{m}\{5\}$, $\dagger 5.6-8(-9) \times 2.3-3(-3.5) \mu \mathrm{m}$ in CR $\{5\}, x=7.2 \times$ $2.8 \mu \mathrm{m}(\mathrm{n}=67)$, with (2-)5-20 small (exceptionally medium-sized) LBs near each end or in each half (lipid content 1-2 or 3-4, varying among collections), LBs fusing in dead spores. Paraphyses filiform till apex, sometimes subapically slightly inflated, straight, rarely slightly flexuous, terminal cell *16-39 × $2-2.7(-3.5) \mu \mathrm{m}\{2\}$, lower cells $* 10-22 \times 1.5-2.7 \mu \mathrm{m}\{2\}$, with very few minute LBs, without refractive vacuoles $\{4\}$.

Pure culture: Radial growth $8.5 \mathrm{~mm} /$ month. Mats first with brown to light brown basic colour, in the inoculum N75, elsewhere blackish brown (T91) to black, at the margin whitish. Aerial mycelium scanty, beige (L91) to greyish (P92), lacking from the outermost half of the mat. Margin indistinct, fimbriate, submerged. Strong hyphal strands lacking. Zonation lacking, sector formation lacking. No colour change in surrounding agar, no yeast-like growth. No anamorph observed.

Phenology: In Central Europe found from December to June. In Finland first mature apothecia found early June and the last on mid-October.

Xerotolerance: Paraphyses and mature asci survive at least five days in the dry state.

Ecology: In Central Europe found on living but partly somewhat bleached leaves or stems of $\mathrm{Ce}$ phaloziella spp., in a mosaic of dense populations of different small mosses (e.g. Campylopus pyriformis), crustose (e.g. ?Trapelia) and fruticose lichens (Cladonia), and jelly algae (Gloeocapsa?) 
covering either raw humus over tree bases or rotten wood, mainly below Pinus sylvestris, at open places with medium insolation, at the border of very acid oligotrophic peatlands (open Vaccinium bogs, transition bogs with Pinus, Molinia coerulea, Calluna vulgaris). The basal hyphae grow very sparsely over the vital green stems and leaves of the liverwort but soon enter each rhizoid and grow extensively within its cells down to their basal ends. The intracellular hyphae have thereby the same diameter as the anchoring hyphae of the apothecium, but are always hyaline (Fig. 5h). Such infected individuals may occur several millimeters apart from the apothecia. The hyphae can also be traced inside the caulidia (Fig. $5 \mathrm{~g}$ ), and below the apothecia rarely some cells of the leaves contain hyphae. Finnish material has been collected on bleached or dead parts of Ptilidium pulcherrimum $\{8\}$ and Lophozia sp. $\{3\}$. Most collections originate from hepatics on conifer trunks in old growth sites in protected areas and the material suggests that the species might prefer older and moister habitats. Of the eleven collections only three originated from ordinary, economically maintained sites. On one occasion the substrate (Ptilidium) grew on an acid stone. On Ptilidium the species co-occurred with, e.g., Epibryon hepaticola (Racov.) Döbbeler, E. diaphanum Döbbeler, Leptomeliola ptilidii Racov., and Fellhanera margaritella (Hulting) Hafellner.

Hyaloscypha hepaticola has repeatedly been observed by P. Wolff at the Miesau locality since 1988 (on Cephaloziella rubella, RP 669, 1214, 1215), but also from two further not very remote sites (Rheinland-Pfalz, NE of Landstuhl, NSG Geißweiher, MTB 6511/4, $236 \mathrm{~m}$ a.s.l., on $C$. rubella, RP 547; Saarland, NNE of Homburg, western part of Königsbruch, MTB 6610/1, 239 m a.s.1., on $C$. divaricata, SL 508, 509, 510). In the estern part of the Königsbruch a collection on C. rubella was noted (SL 305). All three former bogs lie in the "Westpfälzische Moorniederung" over Middle Buntsandstein, with a nordic-subatlantic local climate. The host moss always grows on very acid raw humus (about $\mathrm{pH} 3$ ) with a potential Pinus sylvestris (\& Quercus robur) forest but formerly more or less deforestated and used as pastures that are now mainly covered by $\mathrm{Mo}$ linia coerulea, while they have formerly been moister and inhabited by plants characteristic of transition bogs.
The raw humus derives from rotten tussocks of Molinia but also from Festuca filiformis, Calluna and Salix aurita. The sites gain medium insolation. Extremely dry S-exposed sites without shade are avoided by the discomycete while permanently moist shaded places (e.g. the niches north of the tussocks) are occupied by Campylopus pyriformis. The latter moss as well as the lichens Cladonia chlorophaea and C. coniocrea were regularly found in close contact or in mosaic with the Cephaloziella stands which may cover relatively large areas. The close depressions are bogs in which trees were cut and peat has been harvested. The species was observed by P. Wolff during Dec.-June. A search in autumn, during October 2002, revealed that the host plant was only very reduced and difficult to detect, while $H$. hepaticola was completely absent. Instead, the white taxon was found at that time in one of these localities.

Specimens studied (Finnish grids refer to $27^{\circ} \mathrm{E}$ ): BELGIUM. Prov. Luxembourg. High Ardennes, Vielsalm, Bihain, le Sacrawe, $50^{\circ} 15^{\prime} \mathrm{N}, 5^{\circ} 46^{\prime} \mathrm{E}, 585 \mathrm{~m}$ a.s.l., on Cephaloziella divaricata, 24.III.1999 De Sloover 99C/9 (H.B. 6377). FINLAND. Varsinais-Suomi. Kaarina, Kuusisto, Kappelinmäki, grid 67080:32502, on Ptilidium, 3.VIII.2006 Kukkonen 13 (TUR). Kemiö, Gästerby, Solbacka, grid 66862:32639, on Ptilidium, 4.VIII.2006 Kukkonen 24 (TUR). Nousiainen, Saksala, Kurjenrahka National Park, Pukkipalo, grid 67455:32461, on Ptilidium, 6.X.2006 Kukkonen 64 (TUR). Pukkipalo, grid 67455:32462, on Ptilidium, 6.X.2006 Kukkonen 65 (TUR). Etelä-Häme. Tammela, Liesjärvi National Park, grid 6730:3329, on Lophozia and Ptilidium, 4.VII.2005 Nieminen 10 (TUR). Juupajoki, Hyytiälä Forestry Field Station surroundings, grid 6863:3357, on Lophozia, 6.IX.2005 Nieminen 23 (TUR). Pohjois-Häme. Kuru, Seitseminen National Park, Multiharju, grid 68719:33113, on Ptilidium, 14.X.2006 Kukkonen 76 (TUR). Multiharju, grid 68719:33112, on Ptilidium, 14.X.2006 Kukkonen 80, 81, 82 (TUR). Kainuu. Hyrynsalmi, Ukkohalla, Pieni Tuomivaara, grid 7180:3561, on Lophozia, 7.VI.2005 Huhtinen \& Nieminen 4 (TUR). GERMANY. Rheinland-Pfalz. Westpfälzische Moorniederung, NNE of Homburg, SW of Miesau, Neuwoogmoor, MTB 6610/1, $230 \mathrm{~m}$ a.s.l., peat over sandstone, on Cephaloziella rubella, 2.II.2002 Wolff(H.B. 7111, mis. J. Haedeke). Neuwoogmoor, same location, 20.III.2002 Wolff (H.B. 7119). Neuwoogmoor, same location, 1.IV.2002 Wolff (H.B. 7120).

Further specimens examined only by P. Wolff: on C. divaricata, SL 508, 509, 510; on C. rubella: SL 305, RP $669,1214,1215,547$.

Type collection (not studied): FRANCE. Provence. Dept. Var, Notre-Dame-des-Anges, near Pignans, on stems of living Cephaloziella byssacea $(=C$. divaricata $)$, VI.1924 de Crozals. 
Grelet (1925) described the apothecia as 0.3-0.4 $\mathrm{mm}$ in diam., blackish, with whitish pubescent margins, pale disc, and very short stipes. The narrow, flexuous, obtuse, more or less appressed, pale brownish (at the margin hyaline) hairs measured $30-50 \times 2 \mu \mathrm{m}$, the asci 75-85 $\times 5-7$ $\mu \mathrm{m}$, and the ovoid-oblong to fusoid, sometimes one-septate ascospores 8-12 $\times 3-4 \mu \mathrm{m}$, the latter being without internal granulation. Most of these features fit quite well to our material, except that Grelet observed in sections under the microscope an apparently constant, rather intense blue-green colour of the apothecial base. The excipulum was described consisting of elongate, very narrow, parallel cells, the hairs on which being no more than elongated cortical cells. Possibly Grelet examined the excipulum in surface view where the prismatic shape of the inner cells is easily overlooked. The nearly negative ascus reaction reported by Grelet could be due to the minuteness of the apical ring. In his "Discomycetes de France" (Grelet 1953: 40) he merely repeated the original diagnosis and drawing.
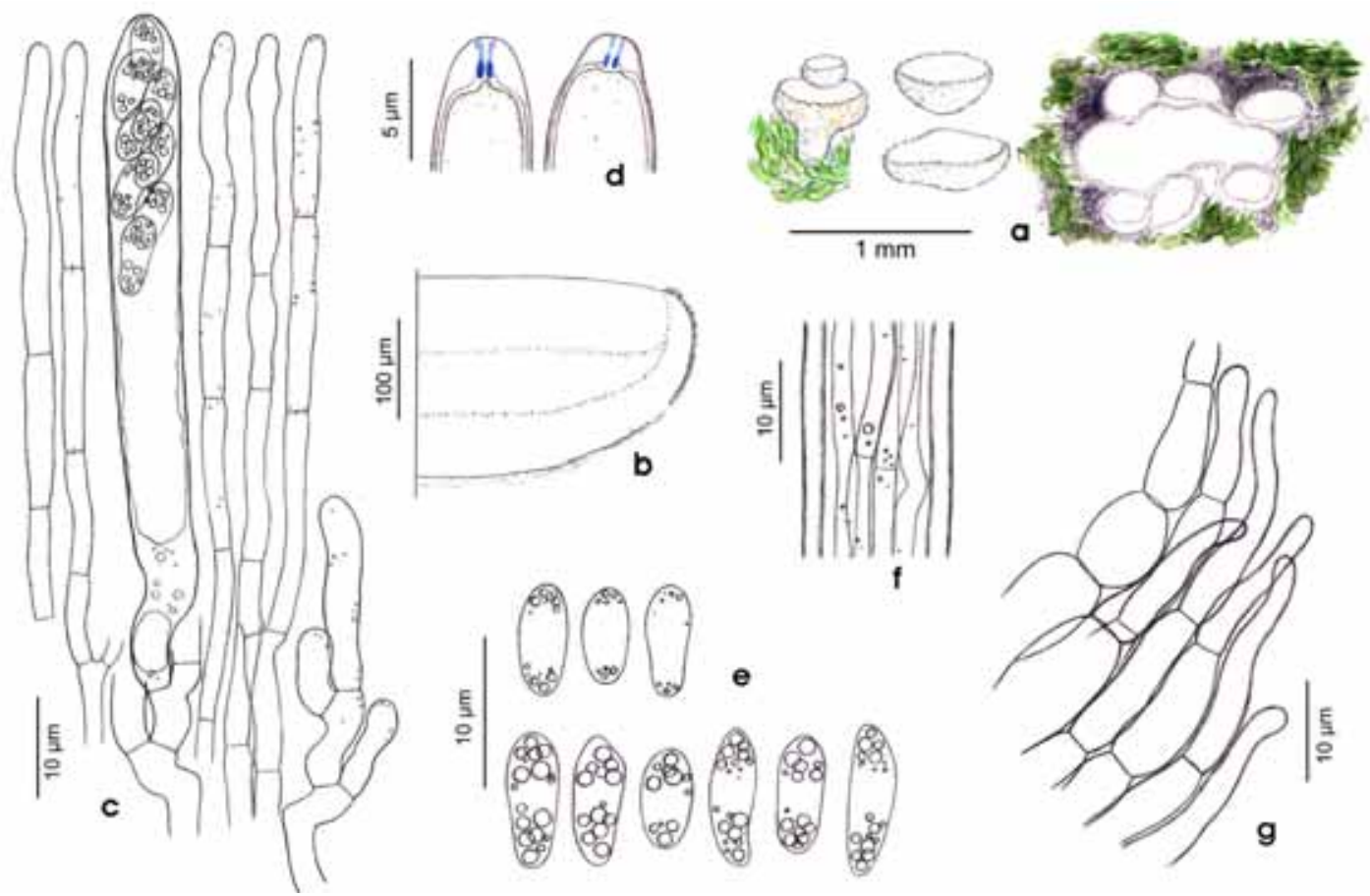

Apothecia sessilia vel breviter stipitata, minuter pilosa; specimina vivide alba vel ochraceo-alba, usque ad $1.2 \mathrm{~mm}$ lata. Excipulum externum textura prismatica, ad marginem textura porrecta. Pili marginali 30-40 × $3 \mu \mathrm{m}$, lageniformi, anguste conici, , tenuiter tunicati, aseptati, exudato resinoso non habentes. Asci euamyloidei, in basi non uncinati. Sporae in statu vivo 6.5-9.5 × 3.2-

Fig. 6. Hyaloscypha albocarpa. Holotype. - 6a) Fresh apothecia on Cephalozia bicuspidata. 6b) Median section of an apothecium. 6c) Ascus with simple-septate base, paraphyses. 6d) Ascus apices. 6e) Mature ascospores (variation in lipid content noted between mature asci of an apothecium). 6f) Rhizoid of Cephalozia infected by hyphae of H. albocarpa. 6g) Ectal excipulum and appressed hairs on flanks. - Del. H.-O. Baral. 
$3.5 \mu \mathrm{m}$, ellipsoideae vel oblonge-ellipsoideae, aseptatae. Paraphyses filiformes vel in apice minuter dilatatae, 2-3 4 m latae, cellulis terminalibus 18-25 um longis.

\section{MycoBank no.: MB513060}

Apothecia scattered or gregarious in small groups, $0.25-0.7(-1.2) \mathrm{mm}$ in diam. when fresh, $(0.12-$ ) $0.16-0.2(-0.4) \mathrm{mm}$ high, receptacle $0.12-0.2$ $\mathrm{mm}$ thick, sessile on a broad or obconical base, or exceptionally with a cylindrical stipe measuring $0.2 \times 0.17 \mu \mathrm{m}$; pure white, watery-white or pale yellowish-cream, very soft, disc slightly concave to flat, margin thin, not protruding, finely fimbriate (especially when young), externally seemingly smooth but densely covered by short, appressed hairs. Hairs on mid flanks *13-24 $\times$ 3-4 $\mu \mathrm{m}$, more or less flexuous, somewhat lageniform, with a shorter or longer, cylindrical apical part 2-2.5 $\mu \mathrm{m}$ wide, apex rounded, hyaline, aseptate, thin-walled, smooth, without exudate $\left(\mathrm{H}_{2} \mathrm{O}\right)$; at margin $* 30-40 \times 3 \mu \mathrm{m}$, gradually tapering to a $1.5 \mu \mathrm{m}$ wide tip, hairs protruding near margin for about 5-10 $\mu \mathrm{m}$, at lower flanks shorter, light brown, appressed to receptacle. Ectal excipulum hyaline, thin-walled or slightly gelatinized, $40-80 \mu \mathrm{m}$ thick near base, of vertically oriented textura prismatica, on lower flanks of t. prismatica(-angularis) $50 \mu \mathrm{m}$ thick, oriented at a $10-45^{\circ}$ or sometimes $45-70^{\circ}$ angle to the

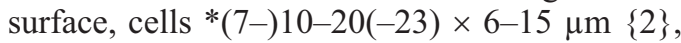
in some apothecia with pale yellowish LBs 1-3.3 $\mu \mathrm{m}$ in diam, on mid flanks and margin $20-30 \mu \mathrm{m}$ thick, margin of t. porrecta oriented at $10-20^{\circ}$, cells $2.5-3 \mu \mathrm{m}$ wide. Medullary excipulum hyaline, in centre of upwards oriented dense t. intricata, on flanks of \pm distinct t. porrecta, individual cells *10-15 × 1.8-2.5(-4) $\mu \mathrm{m}$. Anchoring hyphae sparse, hyaline, $* 1.5-2.5 \mu \mathrm{m}$ thick $\{2\}$, wall smooth, walls firm, glassy, $0.3 \mu \mathrm{m}$ thick, no gelatinous sheath seen. Asci cylindric-clavate, $* 43-57 \times 7.8-8.2\{1\}$ or $* 60-81 \times 6.5-8 \mu \mathrm{m}$ $\{2\}$, protruding $0-10 \mu \mathrm{m}$ beyond paraphyses when mature, $\dagger 50-70 \times 5-6.5 \mu \mathrm{m}\{1\}, 8$-spored, pars sporifera $* 23-27(-33) \mu \mathrm{m}$ long, spores $* / \dagger$ obliquely biseriate, apex medium conical, apical ring faintly to strongly euamyloid (type BB, blue in IKI) $\{2\}$ or slightly hemiamyloid (type $\mathrm{rB}$ blue in IKI, turning indistinctly reddish or negative at high concentration) $\{1\}$, upper part of ring distinctly less reactive, Calycina-type, dome $(\dagger)$ immature 1.6-2 $\mu \mathrm{m}$ thick, mature 0.7-1.6 $\mu \mathrm{m}$, asci arising from simple septa $\{3\}$, never with a basal protuberance. Ascospores (cylindric-)ellipsoid to ellipsoid-clavate or fusoid-clavate, aseptate, *(5.5-)6.5-9.5(-10.3) × (2.8-)3.2-3.5(3.8) $\mu \mathrm{m}\{3\}$, with some small to medium-sized LBs near each end or in each half, lipid content usually 3-4 (LBs up to 1(-1.3) $\mu \mathrm{m}$ diam), apparently less mature spores only $1-2$ (LBs up to 0.5 $\mu \mathrm{m})$. Paraphyses filiform, sometimes subapically slightly inflated, straight to slightly flexuous, terminal cell $* 18-25\{1\} \times 2-2.8(-3.4) \mu \mathrm{m}\{2\}$, lower cells *9-22 × 2-3 $\mu \mathrm{m}\{1\}$, with very few minute LBs, without refractive vacuoles $\{2\}$.

Phenology: The two specimens were collected in November and May.

Xerotolerance: Paraphyses and mature asci survive about 2 weeks in dry state.

Ecology: Thriving on living green leaves (near apex of plant) of Calypogeia muelleriana $\{1\}$, or at base of adult plants (partly on protonemata) of Cephalozia bicuspidata $\{1\}$ and Tetraphis pellucida $\{1\}$, in pure stands $\{2\}$ or mixed with sparse Dicranella sp. $\{1\}$, mosses growing over sandy soil, on tree bases of fallen Picea or standing Pi$n u s$, in rather acid conifer forests and bogs over sandstone; rhizoids below the apothecia were all found to contain abundant hyaline intracellular hyphae.

Specimens studied: GERMANY. Rheinland-Pfalz. Westpfälzische Moorniederung, Miesau, Neuwoogmoor, MTB 6610/1, $230 \mathrm{~m}$ a.s.1., on sandstone, on Cephalozia bicuspidata below Pinus, 1.XI.2002 Wolff (ex H.B. 7240, holotype, M). LUXEMBOURG. Ettelbruck, Beaufort, Esselbur, Elteschmuer, $390 \mathrm{~m}$ a.s.1., on sandstone, on Calypogeia muelleriana below Picea, 13.V.2001 Marson (unpreserved). Esselbur, same locality, on Tetraphis pellucida below Picea, 13.V.2001 Marson (unpreserved).

The morphology of Hyaloscypha albocarpa strikingly matches that of $H$. hepaticola in many respects, including spore size, shape and guttulation, amyloid ring, absence of croziers, hair shape, and structure of the marginal excipulum. For instance, the hairs in the unpreserved find on Calypogeia looked just as those in the Belgian find of $H$. hepaticola. Also the reported variation in size and abundance of LBs within the mature spores is noted in both taxa. H. albocarpa differs by apothecia which (1) completely lack 


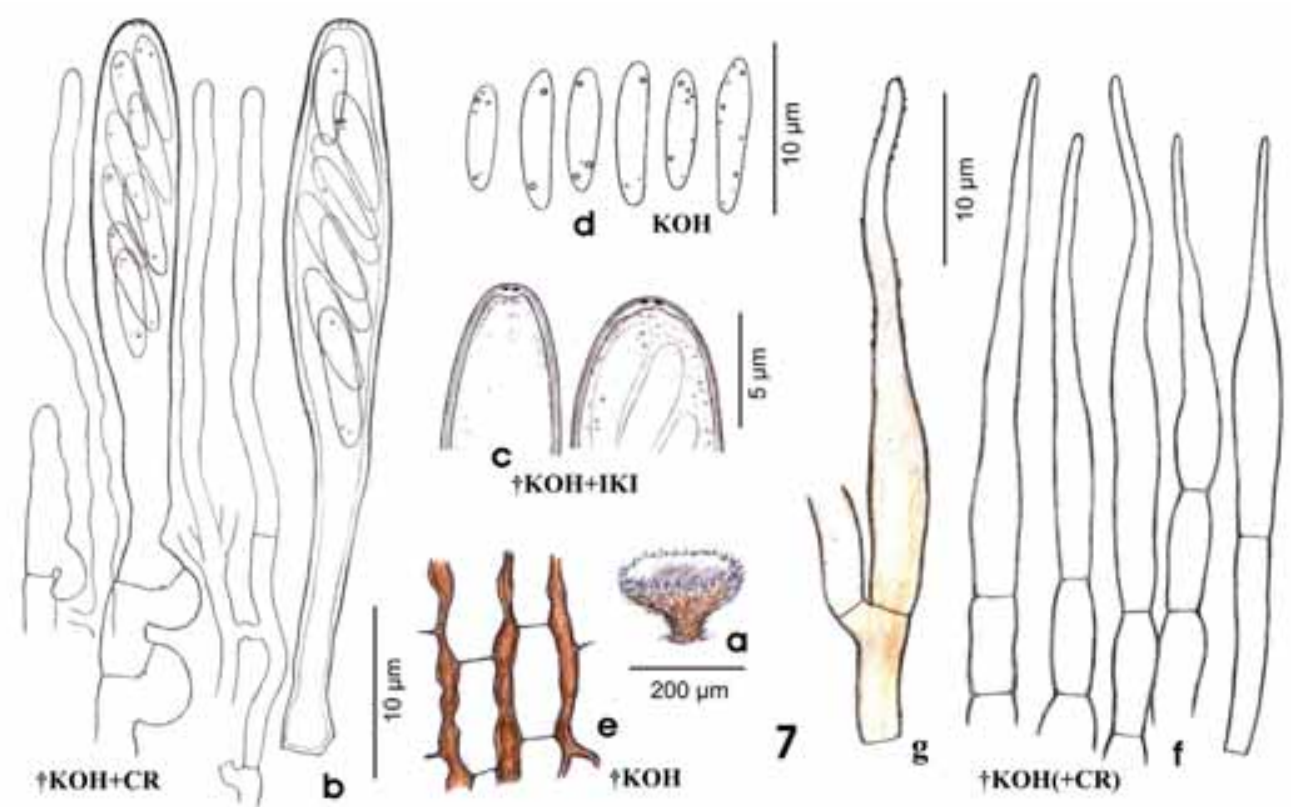

Fig. 7. Hyaloscypha acicularum. Holotype. - 7a) Rehydrated apothecium. 7b) Asci arising from croziers, paraphyses. 7c) Ascus apices. 7d) Ascospores. 7e) Ectal excipulum in surface view. 7f) Marginal hairs. 7g) Hair on stipe. - Del. H.-O. Baral.

any brown pigmentation and (2) usually also a stipe. Some further deviations can be noted, but their taxonomic value is not very clear and needs further research: (3) the asci are slightly smaller and (4) always without a basal protuberance, (5) the excipular cells on the flanks are distinctly larger, especially wider. Both species infect the rhizoids of the host plants, but the present collections of $H$. albocarpa suggest a rather wide range of different families of Bryophyta. Considering the combination of morphological and ecological differences, we believe that $H$. albocarpa is more than an albinotic form of $H$. hepaticola and deserves the rank of a species.

Hyaloscypha acicularum (Velen.) Baral \& Huhtinen comb. nov. - Fig. 7

Basionym: Lachnum acicularum Velen., Monogr. Discom. Bohemiae, p. 245, tab. 9, fig. 4 (1934).

- Fuscoscypha acicularum (Velen.) Svrček, Sydowia 39: 222 (1987).

\section{MycoBank no.: MB513061}

Apothecia scattered, $0.2 \mathrm{~mm}$ in diam. when rehydrated, with cylindrical stipe $0.05 \times 0.04 \mathrm{~mm}$, totally $0.15 \mathrm{~mm}$ high, receptacle $? 0.08 \mathrm{~mm}$ thick, disc (whitish-)greyish, margin finely whitish fimbriate, externally medium brownish, densely covered by hairs, stipe bright to blackish brown, hairy. Hairs on flanks and margin 20-35[-50] $\times$ (2-)2.3-3(-4) $\mu \mathrm{m}$, straight to slightly flexuous, somewhat lageniform, with a shorter or longer, narrow-cylindrical apical part 0.6-0.8 $\mu \mathrm{m}$ wide, apex rounded, hyaline, lower part brownish, aseptate, thin-walled, smooth in $\mathrm{H}_{2} \mathrm{O}$, occasionally with few large lumps of yellowish resinous exudates in unheated lactic acid totally smooth after heating, on stipe light brown with paler apex, lageniform, with ca. $1.2 \mu \mathrm{m}$ wide apex with scattered minute warts. Ectal excipulum bright (ochraceous-)reddish-brown, turning grey-olivaceous to umber-brown in $\mathrm{KOH}$, cortical cells with ca $1-1.5 \mu \mathrm{m}$ thick common walls and very thin septa, on flanks of textura prismatica oriented at a low angle to the surface. Medullary excipulum not examined. Anchoring hyphae at very base of stipe light brown, undulating. Asci fusoid-clavate, $\dagger 33-42.5 \times 5-6.3 \mu \mathrm{m}, 8$-spored, spores obliquely biseriate, apex subhemispherical to medium conical, apical ring IKI-, pale blue when $\mathrm{KOH}$-pretreated (hemiamyloid), dome $\dagger 0.2 \mu \mathrm{m}$ thick, ring 0.7-0.8 $\mu \mathrm{m}$ wide, arising 
from croziers. Ascospores cylindric-ellipsoid to fusoid-clavate, aseptate, $\dagger(5.5-) 6-8(-9) \times(1.5-$ )1.6-1.7(-1.9) $\mu \mathrm{m}$, with a few small LBs near each end (lipid content 1). Paraphyses filiform till apex, straight to slightly flexuous, $\dagger 1-1.5 \mu \mathrm{m}$ wide, septa not distinctly seen, near margin apparently lanceolate and intergrading with hairs.

Specimen studied: CZECH REPUBLIC. Central Bohemian Region. Mnichovice, Hubáčkov, on rotten needles of Pinus sylvestris, associated with Lophodermium pinastri, VIII.1931 Velenovský (PRM 151974, holotype).

Hyaloscypha acicularum is only known from the holotype. Velenovský described and depicted the marginal hairs as 3-septate, 25-50 $\mu \mathrm{m}$ long, tipped with globose "corpuscules" (probably of resinous exudate). When Huhtinen (1990: 53 and in sched.) studied a juvenile apothecium, he saw that the hairs occasionally bear large lumps of yellowish exudate in unheated lactic acid. Such exudate was not observed, neither by Svrček (1987) nor in the present study. Apparently because of the difficulty to decide which of the cells at the hair base belong to the hair or the excipulum, both Svrček and we found the hairs to be shorter $(17-35 \mu \mathrm{m}, 20-35 \mu \mathrm{m}$ in the present study) and aseptate. The ectal excipulum was named as t. oblita by Svrček, because of rather long and narrow cells with thick common walls. The present study suggests that the cells are shorter, i.e. of a thick-walled t. prismatica. Possibly Svrček overlooked some of the septa. Velenovský reported an apothecial diameter of $0.2-0.3 \mathrm{~mm}$, and the black narrow stipe as long as the diameter, while Svrček found a diameter of $0.15-0.25 \mathrm{~mm}$. Velenovský's spore length (3-5 $\mu \mathrm{m})$ is much too short, which is often the case in his descriptions of relatively small spores, while Svrček's data $(5-7 \times 1.5-2 \mu \mathrm{m})$ are quite consistent with those here reported.

According to Svrček (1987), Velenovský (in mscr.) found the species on a single needle of Pinus sylvestris lying on a very thermophilous slope with strong insolation in August after an extraordinarily strong drought. The species is thus undoubtedly xerotolerant. Velenovský noted a resemblance with Antinoa Velen., a small genus of similar acicolous discomycetes with dark stipes and small asci and spores, but lacking hairs on the receptacle.
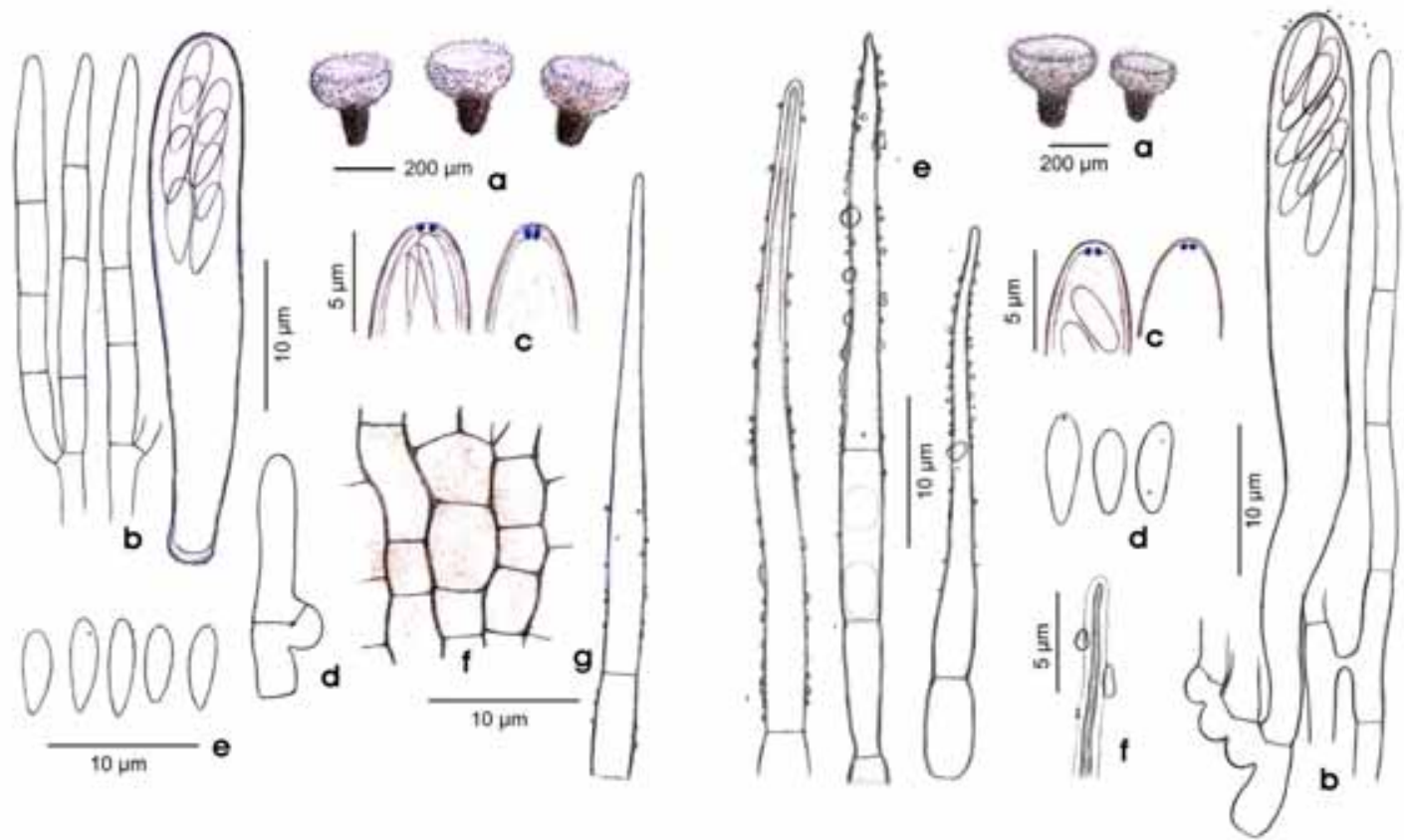

Figs. 8-9. Hyaloscypha fuscostipitata. Fig. 8. H.B. 831. Fig. 9. H.B. 3283. - 8a) Fresh apothecia. 8b) Ascus and paraphyses. 8c) Ascus apices. 8d) Young ascus with crozier. 8e) Mature ascospores. 8f) Ectal excipulum in surface view. 8g) Hair. - 9a) Fresh apothecia. 9b) Ascus arising from croziers, paraphysis. 9c) Ascus apices. 9d) Mature ascospores. 9e) Hairs. 9f) Hair apex showing stained, detached plasma. - Del. H.-O. Baral. 


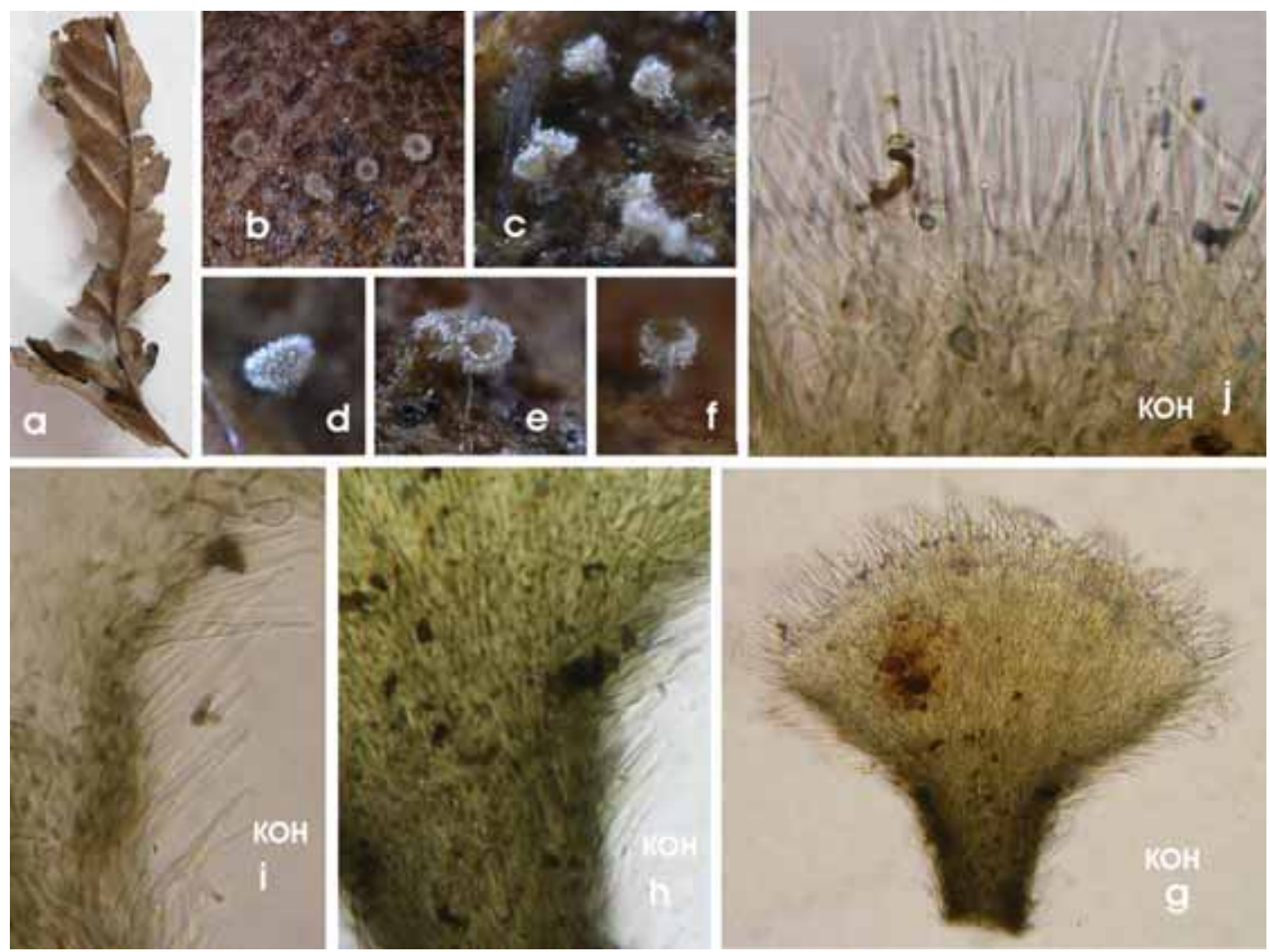

Fig. 10. Hyaloscypha fuscostipitata. H.B. 831. - 10a) Leaf of Carpinus betulus with apothecia on lower face. 10b-f) Rehydrated apothecia. $10 \mathrm{~g}-\mathrm{h}$ ) Apothecium in squash mount. 10i) Apothecial stipe (median section) with projecting hairs. 10j) Hairs at margin (external view). - Photo H.-O. Baral (from over 31 years old herbarium material).

Hyaloscypha fuscostipitata (Graddon) Baral \& Huhtinen comb. nov. - Figs. 8-10

Basionym: Betulina fuscostipitata Graddon, Trans. Br. mycol. Soc. 63 (3): 477, fig. 3B (1974). - Dematioscypha dematiicola var. fuscostipitata (Graddon) Raitv., Česká Mykol. 52(4): 290 (2001).

\section{MycoBank no.: MB513063}

Apothecia gregarious, $0.2-0.3 \mathrm{~mm}$ diam. when dry, with cylindrical stipe $0.06-0.12 \times 0.05-$ $0.08(-0.1) \mathrm{mm}$, totally $0.2-0.3 \mathrm{~mm}$ high, receptacle $0.1 \mathrm{~mm}$ thick, disc whitish-grey to light olivaceous-brownish-grey, margin and exterior whitish-greyish fimbriate ( \pm shining), externally medium greyish-brown, stipe bright to dark olivaveous-brown. Hairs on stipe, flanks and margin $* / \uparrow(22-) 30-40(-48) \times(2.2-) 2.5-3(-3.5)$ $\mu \mathrm{m}\{2\}$, projecting under a ca. $45^{\circ}$ angle, straight to very slightly flexuous, gradually tapered to a $0.5-1 \mu \mathrm{m}$ wide, rounded to acute apex, hyaline or very pale brownish at the base, aseptate or with $1(-2)$ septa near the base, thin-walled, with fine scattered warts in $\mathrm{H}_{2} \mathrm{O}$, MLZ and $\mathrm{KOH}$, in fresh state partly agglutinated as teeth by large lumps of hyaline to yellowish-brown resinous exudate. Ectal excipulum ca 10-12 $\mu \mathrm{m}$ thick, pale to bright umber-brown (olivaceous in $\mathrm{KOH}$ ), $(\dagger)$ thin-walled, with $0.2-0.3 \mu \mathrm{m}$ thick common walls and thin septa, on lower flanks of textura prismatica-angularis-globulosa oriented at a low angle to the surface, cells $\dagger(3-) 4-6(-9) \times 3-6(-$ 7) $\mu \mathrm{m}$, on mid flanks and margin of $t$. prismatica-porrecta, cells $\dagger 5-9 \times 2.5-3 \mu \mathrm{m}$. Medullary excipulum hyaline, of dense, non-gelatinized $\mathrm{t}$. intricata. Anchoring hyphae at very base of stipe abundant, hyaline to light grey-brown, $\uparrow 2-2.5(-$ 3) $\mu \mathrm{m}$, thin-walled. Asci cylindric-clavate, * 28 )35-45(-50) × (5.5-)6 $\mu \mathrm{m}\{2\}, \dagger 28-42 \times 4-5.7$ $\mu \mathrm{m}, 8$-spored, spores $(*)$ obliquely biseriate, 
apex subhemispherical to medium conical, apical ring IKI medium to strongly blue $\{2\}$, rarely some mature asci IKI-, dome (†) immature $0.8-$ $1 \mu \mathrm{m}$ thick, mature $0.4-0.5 \mu \mathrm{m}$, ring $0.8-1 \mu \mathrm{m}$ wide $\{2\}$, arising from croziers $\{2\}$. Ascospores cylindric-ellipsoid to fusoid-clavate, aseptate, *(5-)5.5-7(-8) × (1.6-) $1.8-2.3 \mu \mathrm{m}\{2\}, \dagger 5-6$ $\times 1.5-1.8 \mu \mathrm{m}$, without or with very few minute LBs near each end (lipid content 0-0.5). Paraphyses filiform or often distinctly tapered near apex, straight to slightly flexuous, terminal cell $\dagger 7-14 \times 1.5-1.8 \mu \mathrm{m}$, lower cells $5-8 \times 1.6-1.8$ $\mu \mathrm{m}$, without refractive vacuoles $\{1\}$.

Phenology: Occurring from September to October.

Ecology: On lower face of decayed, non-sceletonized leaves of Carpinus betulus $\{1\}$, involucres of Castanea sativa $\{1\}$, lying on the ground.

\section{Specimens studied: GERMANY. Baden-Württemberg. Stuttgart, Ditzingen, Nippenburger Wald, MTB 7120/1, $300 \mathrm{~m}$ a.s.1., on previous year's leaves of Carpinus betu- lus, 19.IX.1976 Baral (H.B. 831). Tübingen, Heuberg, MTB 7420/3, $495 \mathrm{~m}$ a.s.1. on previous year's involucres of Castanea sativa (on bases of spines), 17.X.1987 Baral (H.B. 3283). UNITED KINGDOM. Warwickshire. Coleshill, on Betula leaves, X.1972 Clark (K, ex Herb. Graddon 2245, holotype).}

This apparently rare species described from U.K. (Warwickshire) has also been found in Germany (Baral \& Krieglsteiner 1985: 47). It thrives on dead fallen leaves of Betula, Rubus and Carpinus (Ellis \& Ellis 1985, Baral \& Krieglsteiner 1.c.). Castanea involucres are reported as a new substrate in the present paper. The species is very closely related to Hyaloscypha acicularum, but appears to be separable at the species level by the thickness of the bright-coloured common walls between the cells of the ectal excipulum on the flanks, and the thickness of the apical ascus wall, in combination with the substrate (angiospermic vs. coniferous, see the above key).

Hyaloscypha fuscostipitata is easy to separate from $H$. hepaticola by its ecology (saprophytic vs. parasitic), by its shorter asci and smaller (especially narrower) spores with almost absent oil drops. Further differences are found in the hairs which project on stipe and flanks in $H$. fuscostipitata while being appressed and also less tapering in $H$. hepaticola, in the ascus base (croziers in $H$. fuscostipitata vs. simple septa in H. hepaticola), and in much shorter terminal cells of paraphyses. The distinct lumps of exudate on the hairs were only seen in the fresh state. They dissolve in MLZ, CR or $\mathrm{KOH}$ for which reason they are here termed resinous. However, very fine warts c. $0.5 \mu \mathrm{m}$ high are inert to these reagents and are already visible in water mounts.

Acknowledgements: Dr. Peter Döbbeler is thanked for the identification of Hyaloscypha hepaticola, which initiated the present study. Guy Garcia, Peter Wolff, Mikael Kukkonen and Ari-Pekka Nieminen are thanked for their observations on material of $H$. hepaticola. This work was supported by the Ministry of the Environment, Finland, as a part of the research programme of deficiently known and threatened forest species (PUTTE).

\section{References}

Baral, H.-O. 1989: Die Calycellina-Arten mit 4sporigen Asci. - Beitr. Kenntn. Pilze Mitteleuropas 5: 209236.

Baral, H.-O. 1992: Vital versus herbarium taxonomy: morphological differences between living and dead cells of Ascomycetes, and their taxonomic implications. - Mycotaxon 44 (2): 333-390.

Baral, H.-O. \& Krieglsteiner, G.J. 1985: Bausteine zu einer Ascomycetenflora der Bundesrepublik Deutschland: In Süddeutschland gefundene Inoperculate Discomyceten - mit taxonomischen, ökologischen, chorologischen Hinweisen und einer Farbtafel. - Beihefte Z. Mykol. 6: 1-160.

Cailleux, A. 1981: Code des Couleurs de Sols. Boubée.

Cubeta, M.A., Echandi, E., Abernethy, T. \& Vilgalys, R. 1991: Characterization of anastomosis groups of binucleate Rhizoctonia species using restriction analysis of an amplified ribosomal RNA gene. - Phytopathology $81(11)$ : $1395-1400$.

Ellis, M.B. \& Ellis, J.P. 1985: Microfungi on land plants. An identification handbook. - Croom Helm, London \& Sydney. 818 pp.

Gardes, M. \& Bruns, T.D. 1993: ITS primers with enhanced specificity for basidiomycetes - application to the identification of mycorrhizae and rusts. - Mol. Ecol. 2: 113-118.

Graddon, W.D. 1974: Some new discomycete species. Trans. Br. Mycol. Soc. 63(3): 475-485.

Grelet, L.-J., 1925 : Discomycètes nouveaux. - Bull. trim. Soc. mycol. Fr. 41: 83-86.

Grelet, L.-J., 1953 : Les Discomycètes de France 23. Urceolella, Trichopeziza, Pyrenopeziza. - Rev. myc. 18: 24-48.

Huhtinen, S. 1990 : A monograph of Hyaloscypha and allied genera. - Karstenia 29(2): 45-252.

Kirk, P.M. \& Spooner, B.M. 1984: An account of the fungi of Arran, Gigha and Kintyre. - Kew Bull. 38: 503-597.

Liu, Y.J., Whelen, S. \& Hall, B.D. 1999: Phylogenetic relationships among ascomycetes: evidence from 
an RNA polymerase II subunit. - Mol. Biol. Evol. 16(12): 1799-1808.

Lohtander, K., Myllys, L., Sundin, R., Källersjö, M. \& Tehler, A. 1998: The species pair concept in the lichen Dendrographa leucophaea (Arthoniales): analyses based on ITS sequences. - Bryologist 101(3): 404-411.

Lohtander, K., Oksanen, I. \& Rikkinen, J. 2002: A phylogenetic study of Nephroma (lichen-forming Ascomycota). -Mycol. Res. 106(7): 777-787.

Myllys, L., Lohtander, K., Källersjö, M. \& Tehler, A. 1999: Sequence insertions and ITS data provide congruent information on Roccella canariensis and R. tuberculata (Arthoniales, Euascomycetes) phylogeny. - Mol. Phylogenet. Evol. 12(3): 295-309.

Myllys, L., Lohtander, K. \& Tehler, A. 2001: ß-tubulin, ITS and group I intron seqiences challenge the species pair concept in Physcia aipolia and P. caesia. - Mycologia 93(2): 335-343.

Raitviir, A. \& Galán, R. 1993: Notes on Spanish glassyhaired Hyaloscyphaceae. - Sydowia 45(1): 34-54.

Reeb, V., Lutzoni, F. \& Roux, C. 2004: Contribution of RPB2 to multilocus phylogenetic studies of the euascomycetes (Pezizomycotina, Fungi) with special emphasis on the lichen-forming Acarosporaceae and evolution of polyspory. - Mol. Phylogenet. Evol. 32: 1036-1060.

Rehner, S.A. \& Samuels, G.J. 1995: Molecular systematics of the Hypocreales: a teleomorph gene phylogeny and the status of their anamorphs. - Can. J. Bot. 73 (Suppl. 1): S816-S823.

Svrček, M. 1987 (“1986”): Über zwei neue Discomyzetengattungen. - Sydowia 39: 219-223.

Swofford, D.L. 2002: PAUP*. Phylogenetic Analysis Using Parsimony (*and other methods). Version 4.0b 10. - Sinauer Associates, Sunderland, Massachusetts.

Thompson, J.D., Gibson, T.J., Plewniak, F., Jeanmougin, F. \& Higgins, D.G. 1997: The Clustal X windows interface: flexible strategies for multiple sequence alignment aided by quality analysis tools. - Nucleic Acids Res. 25(24): 4876-4882.

Velenovský, J., 1934: Monographia Discomycetum Bohemiae. Pragae.

Velenovský, J., 1947: Novitates mycologicae novissimae. - Opera Bot. Cechica 4: 1-158.

Vilgalys, R. \& Hester, M. 1990: Rapid gene identification and mapping of enzymatically amplified ribosomal DNA from several Cryptococcus species. - J. Bacteriol.172(8): 4238-4246.

White, T.J., Bruns, T., Lee, S. \& Taylor, J. 1990: Amplification and direct sequencing of fungal ribosomal RNA genes for phylogenetics. -In: Innis, M.A., Gelfand, D.H., Sninsky, J.J. \& White, T.J., (eds) PCR Protocols: a Guide to Methods and Applications, pp. 315-322. Academic Press, San Diego. 